\title{
MENGEMBANGKAN KREATIVITAS KEPEMIMPINAN DALAM PENGELOLAAN DI LEMBAGA PENDIDIKAN ANAK USIA DINI
}

\author{
Oleh: \\ Eka Sapti Cahyaningrum \\ Eka sapticn@uny.ac.id \\ PAUD FIP Universitas Negeri Yogyakarta
}

\begin{abstract}
Abstrak
Kepemimpinan lembaga pendidikan merupakan elemen dasar dalam pengembangan lembaga secara keseluruhan. Tanpa adanya kepemimpinan yang baik akan berakibat pada lemahnya pencapaian tujuan organisasi pendidikan. Berbicara mengenai kepemimpinan pada lembaga pendidikan sangat terkait dengan kesiapan sumber daya manusia yang ada di dalamnya. Elemen pokok kemajuan lembaga pendidikan khususnya pada Pendidikan Anak Usia Dini terletak pada kesiapan seluruh komponen yang meliputi figur kultur, dan struktur dalam organisasi tersebut. Upaya mengembangkan kreativitas kepemimpinan dalam pengelolaan di lembaga pendidikan anak usia dini sangat tergantung pada komitmen setiap unsur di dalamnya. Pencapaian tujuan organisasi lembaga pendidikan anak usia dini teritegrasi dalam visi organisasi dan melalui pemimpin yang kreatif mampu membawa perubahan kea rah kemajuan. Pada sisi yang lain kualitas dukungan seluruh stake holder berpengaruh dalam membantu usaha-usaha lembaga pendidikan.
\end{abstract}

Kata kunci: Kreativitas, Kepemimpinan, Pendidikan Anak Usia Dini

\begin{abstract}
Leadership education institutions is a basic element in the development of the institution as a whole. In the absence of good leadership will result in weak educational attainment of organizational goals. Speaking of leadership in educational institutions is related to the readiness of human resources in it. Essential elements of progress educational institutions, especially in early childhood education lies in the readiness of all components which include figures of culture and structure within the organization. Efforts to develop creativity in leadership in the management of early childhood education institutions depends on the commitment of every element in it. The achievement of organizational goals early childhood education institutions teritegrasi in the vision of the organization and through the creative leader capable of bringing change towards progress. On the other hand the quality of the support of all stakeholders influential in assisting the efforts of educational institutions.
\end{abstract}

Keywords: Creativity, Leadership, Early Childhood Education

\section{PENDAHULUAN}

Lembaga Pendidikan Anak Usia Dini seiring dengan perkembangannya dituntut untuk senantiasa meningkatkan kualitasnya. Esensi kualitas yang diharapkan adalah peningkatan kompetensi tenaga pendidik, fasilitas, metode, dan dana. Tanggung jawab guru pendidikan anak usia dini (PAUD) saat ini semakin berat, hal itu cukup beralasan mengingat semakin ketatnya persaingan hidup dan semakin cepatnya perubahan yang terjadi di bidang ilmu pengetahuan dan teknologi, budaya, maupun perkembangan masyarakat secara lebih luas. Fungsi guru bukan hanya sekedar mengajar dan mendidik tetapi ia harus mengenal dirinya sendiri sebagai seorang pribadi yang terpanggil untuk senantiasa mendampingi peserta didik untuk belajar. Lembaga 
PAUD merupakan wahana guru dan siswa bertemu, berinteraksi untuk belajar.
Kondisi lembaga PAUD di Daerah Istimewa Yogyakarta sebagai berikut.

Tabel 1. Jumlah Lembaga Paud di DIY tahun 2016

\begin{tabular}{|l|c|c|c|c|c|}
\hline \multirow{2}{*}{ No } & \multicolumn{4}{|c|}{ Jumlah lembaga } & \multirow{2}{*}{ Total } \\
\cline { 2 - 5 } & TK & KB & TPA & SPS & \\
\hline 1. & 2.121 & 1.610 & 246 & 1.741 & 5.718 \\
\hline
\end{tabular}

Sumber: Sapulidi Riset Center (sapulidinews.com)

Sementara itu berdasarkan data dari

Pusat Data dan Statistik Pendidikan Kementerian Pendidikan dan Kebudayaan pada tahun 2014 Angka Partisipasi Kasar penduduk usia 3-6 tahun pada lembaga PAUD di daerah Istimewa Yogyakarta mencapai $98,98 \%$. Data tersebut sangat mengembirakan, di mana orang tua memiliki kesadaran yang memadai tentang pentingnya pendidikan sejak dini. Bahkan dalam kurun waktu lima tahun terakhir perkembangan lembaga PAUD di daerah Istimewa Yogyakarta naik secara signifikan. Bagi sebagian siswa sekolah/lembaga PAUD sebagai wahana belajar seringkali menjadi tidak nyaman dan tempat yang tidak menyenangkan. Siswa yang merasa tertekan adalah siswa yang tidak mampu mengikuti beradaptasi dengan baik sehingga terkucilkan, siswa yang kesulitan secara ekonomi dan sosial, maupun siswa yang mengalami permasalahan psikologis, seperti salah dalam pengasuhan dan kendala lainnya. Pengelolaan lembaga PAUD yang baik akan berdampak pula terhadap kualitas layanan yang diberikan. Masyarakat sebagai pelanggan memiliki tuntutan untuk memperoleh pendidikan yang memadai meskipun mereka sendiri belum banyak mmberikan konstribusi dalam mendukung pendidikan di lembaga PAUD.

\section{MENJADI KEPALA SEKOLAH PROFESIONAL}

Kepala Lembaga PAUD berperan dalam mengembangkan kualitas lembaganya secara berkelanjutan. Aspek yang dikembangkan meliputi sumber daya manusia, fasilitas, metode, dan pendanaan. Untuk itu ia dituntut meningkatkan wawasan dan pengetahuannya sehingga peka terhadap perubahan dan tuntutan masyarakat akan pendidikan. Ernest (2010), dalam judul papernya Principal quality practice in alberta. menunjukkan bahwa terdapat tujuh dimensi yang mendasari perkembangan profesional yang akan meningkatkan keefektifan kepala sekolah dalam menjalankan tugasnya. 7 dimensi tersebut adalah: 1) fostering effective relationship, 2) embodying visionary leadership, 3) leading a learning community, 4) providing instructional leadership, 5) developing and vacilitating leadership, 6) managing school operations and resources, 7) understanding and reporting to the larger societal context.

Pengembangan kompetensi kepala sekolah merupakan salah satu agenda utama untuk memberdayakan lembaga secara keseluruhan. Kepala sekolah professional harus bias menjalin relasi, visioner, mampu memimpin dalam komunitas pembelajaran, memberikan layanan kepemimpinan, membangun dan memfasilitasi kepemimpinan, mengelola sumber daya dan operasional sekolah, dan memahami pelaporan dalam konteks social yang lebih besar. Sumber daya manusia khususnya guru merupakan sebuah profesi yang memadukan unsur pengetahuan, keterampilan dan sikap, serta mampu dan mau menerima perbedaan setiap individu peserta didik.

Kepemimpinan telah digambarkan sebagai suatu tindakan menyeimbangkan antara diri sendiri dan orang lain. Para pemimpin yang efektif menyadari kepribadian nya dan bagaimana faktorfaktor atau tugas operasional sehari-hari mempengaruhi hubungan nya dengan orang lain. Para pemimpin yang efektif memahami bagaimana orang lain berbeda 
dalam temperamen dan harapan dan bagaimana mereka yang terbaik mungkin termotivasi. Kepala sekolah harus belajar untuk berhubungan dengan pihak internal dan eksternal sehingga mampu memaksimalkan potensi lembaganya.

\section{KREATIVITAS PEMIMPIN LEMBAGA}

Pemimpin lembaga pendidikan yang kreatif tampak dari performa lembaga secara keseluruhan, karena ia mampu mengelola dengan baik sekaligus dapat merencanakan dan mengembangkan dengan baik pula. Ima Ismara (2009) antara lain mengemukakan beberapa hambatan mental yang dapat mengurangi daya imajinasi pemimpin diantaranya:

1. Pandangan hidup yang sempit,

2. Kepercayaan terhadap takhayul,

3. Keputusasaan,

4. Kurangnya kepercayaan pada diri sendiri,

5. Kesombongan,

6. Kedengkian dan iri hati,

7. Kebodohan, dan

8. Kekhawatiran akan kegagalan.

9. Budaya masyarakat

Kita harus membuang sejauh mungkin setiap hambatan mental yang mengganggu proses berpikir kita. Daya imajinasi baru mempunyai arti bagi hidup kita apabila bercampur dan bekerjasama dengan daya pikiran kita. Pikiran kita dapat berakibat dua hal, mungkin menolong mungkin juga menghambat usaha kita. Pemimpin pendidikan yang kreatif senantiasa mengedepankan inovasi terhadap kesulitan yang dihadapi.

Zamroni (2000: 56) mengemukakan pentingnya dukungan dalam rangka pembinaan dan peningkatan profesional guru melalui kegiatan professional kesejawatan yang baik, harmonis, dan obyektif yang antara lain dilengkapi dengan:

a. Wadah/ kelembagaan, yang merupakan organ non struktural dan dikembangkan berdasarkan bidang studi atau rumpun biang studi pada masing-masing sekolah.

b. Bentuk kegiatan, merupakan aktivitas kegiatan yang dilakukan dengan prinsip saling asah, asuh dan asih. Kegiatan kelompok ditujukan untuk: 1). Meningkatkan kualitas dan kemampuan dalam pelaksanaan proses belajar mengajar. 2). Meningkatkan penguasaan dan pengembangan keilmuan khususnya bidang studi yang menjadi tanggung jawabnya. 3). Meningkatkan kemampuan untuk mengkomunikasikan masalah akademis.

c. Mekanisme, kegiatan kesejawatan dilaksanakan secara rutin dan berkesinambungan.

d. Standar profesional guru, aktivitas yang dilakukan bersifat komprehensif dan total mencakup presentasi, observasi, penilaian, kritik, tanggapan, saran, dan bimbingan.

\section{GURU SEBAGAI PEMIMPIN}

Pada lembaga PAUD guru merupakan tokoh sentral yang berhadapan langsung dengan anak didiknya. Guru PAUD berperan sebagai manajer, pemimpin sekaligus teladan atau dalam konsep ajaran Ki Hajar Dewantara adalah Ing Ngarsa Sung Tuladha. Salah satu faktor yang harus diperhatikan dalam pembaharuan pendidikan dan pengajaran di Indonesia adalah guru yang harus mampu mempengaruhi siswa, berpandangan luas dan memiliki kewibawaan, artinya mempunyai kesungguhan, suatu kekuatan, sesuatu yang dapat memberikan kesan dan pengaruh. Jadi diperlukan pengetahuan, teknik mengajar, juga pengalaman untuk mempengaruhi. (Cece wijaya dkk: 1992)

Belajar dan membelajarkan anak usia dini memerlukan strategi khusus. Strategi yang dimaksud berkaitan dengan pola belajar, penyampaian materi maupun aspek lainnya dalam kegiatan belajar mengajar. Belajar pada anak usia dini tidak dapat disamakan dengan belajar pada anak 
remaja atau dewasa. Pola yang berbeda dalam pengajaran tersebut berpengaruh terhadap keberhasilan tujuan pengajaran. Dalam arti luas, pendidikan adalah setiap proses di mana seseorang memperoleh pengetahuan (knowledge acquisition), mengembangkan

kemampuan/keterampilan

(skills developments) sikap atau mengubah sikap (attitute change). Pendidikan merupakan proses berlangsungnya pembentukan jati diri anak melalui transformasi anak didik agar mencapai hal-hal tertentu sebagai akibat proses pendidikan yang diikutinya.

\section{MENCIPTAKAN YANG EFEKTIF \\ LINGKUNGAN}

Kondisi lingkungan di lembaga pendidika dapat dibedakan menjadi internal dan eksternal. Pada setiap lembaga pendidikan khususnya PAUD faktor dominan yang mempengaruhi keberhasilan pendidikan sangat beragam, dan bersifat individual antar lembaga. Pada beberapa lembaga PAUD seringkali ditemukan lembaga yang telah memiliki dukungan memadai secara internal dan eksternal. Penciptaan lingkungan lembaga pendidikan anak usia dini sangat penting sebagai upaya utuk memberikan layanan terbaik. Secara umum kondisi lingkungan akan efektif dipengaruhi oleh tiga hal, yaitu.
a. Kultur
b. Struktur, dan
c. Figur

Ke-tiga elemen itu merupakan dasar dalam menentukan keberhasilan pengelolaan lembaga secara maksimal. Kultur dapat diciptakan melalui komitmen dari seluruh warga lembaga dengan menekankan pada pencapaian visi. Sementara itu struktur sebuah lembaga dibangun melalui kepercayaan dan manajemen yang baik sehingga dapat mengembangkan berbagai unsur secara maksimal. Figur sebuah lembaga pendidikan sangat ditentukan oleh kedewasaan setiap warga sebagai bentuk aktualisasi dan kinerja yang diharapkan.

\section{PERENCANAAN LEMBAGA PAUD}

KUALITAS

Kualitas sebuah lembaga pendidikan ditentukan oleh dukungan seluruh warganya, untuk itu perlu adanya kesepahaman antara berbagai elemen guna terwujudnya suasana kondusif. Mutu merupakan ukuran yang harus dijaga dan diraih pada beberapa aspek, melalui mutu lembaga pendidikan akan memiliki target yang jelas di dalam melangkah. Nanang Fattah (2009: 1) menjelaskan proses perencanaan sebagai upaya penentuan tujuan atau sasaran yang hendak dicapai serta menetapkan jalan dan sumber daya yang diperlukan untuk mencapai tujuan itu secara efektif dan efisien. Untuk dapat mencapai tujuan seefisien dan seefektif mungkin, maka diperlukan langkah-langkah strategis yang harus dilakukan. Langkah-langkah strategis tersebut adalah:

1) Merumuskan tujuan

Tujuan perlu dirumuskan untuk mendapatkan hasil yang maksimal dengan cara seefisien dan seefektif mungkin. Perumusan tujuan ini akan lebih baik jika dilakukan atau dirumuskan oleh semua pihak. Dalam merumuskan tujuan perlu memperhatikan beberapa beberapa hal, salah satunya adalah analisis SWOT (Strength, Weakness, Opportunity, Treatment). Secara rinci sebagai berikut:

a) Strength

Strength atau kekuatan dapat dilihat sebagai sebuah kunci dalam merumuskan tujuan. Kekuatan merupakan factor internal yang menjadi daya dukung optimal dalam mencapai visi lembaga pendidikan. Di lembaga PAUD faktor kekuatan bisa berasal dari sumber daya manusia, fasilitas, metode, maupun pendanaan.

b) Weakness

Weakness atau kelemahan. Ketika merumuskan tujuan organisasi sekolah, maka akan sangat membantu ketika kita memahami kelemahan yang 
dimiliki. Kelemahan merupakan factor internal yang berdampak secara langsung dengan lembaga pendidikan. Ketika kita mengetahui kelemahan organisasi dengan baik, maka perencanaan tujuan organisasi dapat tersusun lebih sistematis. Sehingga akan diperoleh hasil secara efektif dan efisien.

c) Opportunity

Peluang merupakan factor eksternal yang berpengaruh langsung maupun tidak langsung dengan lembaga. Peluang ini tentunya merupakan sebuah kesempatan yang baik bagi organisasi untuk dapat berkembang secara maksimal. Dalam mengambil pilihan peluang yang tersedia, harus dilihat dampak positif dan negatifnya bagi organisasi. Dengan memilih peluang yang tepat, maka tujuan organisasi akan dapat terwujud secara efektif dan efisien.

d) Treat

Ancaman merupakan faktor yang . Ancaman ini dapat diminimalkan ketika dipahami dengan baik. Dengan menguasai ancaman yang ada, maka langkah-langkah dalam merumuskan tujuan organisasi harus dicermati secara detail. Efek langsung dan tidak langsung dari ancaman tergantung kesiapan organisasi dalam menghadapinya.

2) Memilih dan memilah jenis kegiatan yang akan dilaksanakan

Dalam perencanaan, sangat penting untuk melakukan pilihan terhadap kegiatan yang akan dilaksanakan. Kegiatan-kegiatan ini perlu dipilih dan ditentukan melalui penentuan skala prioritas. Dengan adanya skala prioritas, akan membantu organisasi dalam mencapai tujuan organisasi secara efektif dan efisien. Karena kegiatan tersebut akan dilaksanakan secara sistematis dan berkelanjutan.

3) Identifikasi sumber daya manusia

Dalam merumuskan perencanaan, perlu dilakukan identifikasi sumber daya yang dimiliki oleh sebuah organisasi. Sumber daya ini perlu diidentifikasi untuk menentukan kebijakan yang akan diterapkan dalam sebuah organisasi. Termasuk didalamnya akan ditentukan apakah memerlukan pengadaan, mutasi, pemberhentian maupun pembinaan.

a. Pengorganisasian

Nanang Fattah, (2009: 52) menyampaikan pengertian pengorganisasian yang dapat dijabarkan sebagai pelaksanaan kegiatan yang dilakukan oleh sekumpulan orang dengan system kerja sama untuk mencapai tujuan yang telah ditetapkan. Dalam pengorganisasian harus sesuai dengan tujuan awal yang telah ditetapkan, sehingga dalam pelaksanaannya, pengorganisasian tidak boleh lepas dari kerangka berpikir sebelumnya. Dalam pembinaan, pengorganisasian harus selalu dikaitkan dengan tujuan awal pembinaan yang akan dilakukan.

b. Pengendalian/Organizing

Gilley \& Eggland (1993: 107) menjabarkan organizing is based on the goals and objectives establish through the planning process. Menurut Gilley \& Eggland, pengendalian didasarkan pada tujuan akhir yang akan dicapai dan yang sudah ditentukan diperencanaan.

c. Evaluasi

Evaluasi menurut Hasan (2009:37) merupakan sebuah kegiatan yang bertujuan untuk merumuskan apa yang harus dilakukan, mengumpulkan informasi, dan menyajikan informasi yang berguna bagi penetapan alternatif keputusan. Evaluasi dapat dilakukan oleh semua pihak, baik intern maupun ekstern. Hasil evaluasi yang dilakukan oleh ke 2 belah pihak akan saling melengkapi informasi yang diperoleh tentang organisasi. 


\section{SIMPULAN}

Unsur kemajuan sekolah adalah
komitmen warganya untuk secara
bersama-sama menuju tujuan yang telah
ditetapkan. Lembaga pendidikan anak usia
dini merupakan organisasi yang bersifat
terbuka, karena sifatnya tersebut ia rentan
terhadap situasi di lingkungannya baik
internal maupun eksternal.

Kreativitas pemimpin lembaga sangat tergantung pada upaya pemenuhan indikator yang telah ditetapkan. Pemimpin yang kreatif tergambar dari kemajuan lembaga pendidikan yang dipimpinnya. Unsur itu sangat berpengaruh dalam kemajuan lembaga pendidikan.

Sarana yang paling tepat untuk merumuskan tujuan lembaga adalah melalui pelibatan seluruh komponen internal dan eksternal yang mendukung organisasi secara memadai.

\section{DAFTAR PUSTAKA}

Cece Wijaya, dkk. (1992). Upaya Pembaharuan Dalam Pendidikan dan Pengajaran. Bandung: PT.

Remaja Rosdakarya

Ennest, R. (2010). Principal quality practice in alberta. Education 900 introduction paper.

Fattah, Nanang. (2009). Landasan manajemen pendidikan islam. Bandung: Remaja Rosdakarya.

Gilley, J.G. and S.A. Eggland. (1993). Principles of human resource development. Massachusetts: Addition-Wesley Pub.Co.Inc.Toronto.

Hasan, Hamid. (2009). Evaluasi kurikulum. Bandung: PT Remaja Rosdakarya
Ismara, Ima. 2009. Bahan Diklat Kepala Sekolah dan Pengawas. Jakarta: Depdiknas.

Zamroni. (2000). Paradigma Pendidikan Masa Depan. Yogyakarta: BIGRAF Publishing. 